\title{
Explaining the Party Unity of Governing Parties in Mexico*
}

\author{
La unidad partidista de los partidos gobernantes en México
}

\section{YEN-PIN SU}

National Chengchi University, Taiwan

\section{FABRICIO A. FONSECA}

Tamkang University, Taiwan

\begin{abstract}
Previous studies have found that party unity in legislative voting tends to be higher for governing parties, but little is known about why some governing parties have higher levels of party unity than others. This study aims to fill the empirical void by conducting analyses of governing parties' unity in legislative voting. We argue that presidential popularity matters for explaining variation in vote unity of governing parties because presidential approval is an important psychological component in executive-legislative relations. Focusing on deputies from the incumbent parties in roll-call votes for executive-sponsored bills in Mexico from 1998 through 2018, we find that the level of a governing party's unity increases with higher presidential approval. The results are robust to a number of sensitivity tests and to controlling for potential endogeneity.
\end{abstract}

Keywords: Party Unity, Presidential Approval, Institutional Revolutionary Party, Legislative Voting, Mexico.

\section{RESUMEN}

Estudios anteriores han demostrado que la unidad partidista durante votaciones legislativas tiende a ser mayor en el caso de los partidos gobernantes. Sin embargo, poco se sabe sobre por qué algunos partidos en el poder presentan mayores niveles de unidad que otros. Este estudio busca contribuir a llenar dicho vacío empírico por medio de los análisis de unidad de los partidos gobernantes en votaciones legislativas. Nuestro argumento principal gira en torno a la relevancia de la popularidad del jefe del Ejecutivo para explicar la variación en la unidad del voto legislativo por parte del partido en el poder. Ello se debe a que los niveles de aprobación presidencial son un componente psicológico importante en las relaciones entre el Ejecutivo y el Legislativo. Tomando el caso de los votos nominales de los diputados de partidos en el gobierno en México desde 1998 hasta 2018, durante la aprobación de iniciativas de ley promovidas por el Ejecutivo, encontramos que el nivel de unidad del partido gobernante tiende a crecer ante una mayor aprobación presidencial. Los resultados obtenidos son robustos ante un determinado número de pruebas de sensibilidad $y$ de control por endogeneidad potencial.

Palabras clave: Unidad partidista, aprobación presidencial, Partido Revolucionario Institucional, votación legislativa, México.

We appreciate the feedback and suggestions from L.J Zigerell, two anonymous reviewers of this article, and Professor Francisco Urdinez. The Taiwan Ministry of Science and Technology (MOST 109-2410-H-032-003MY2 ) supported the work of Fabricio Fonseca on this article. 


\section{INTRODUCTION}

Conventional wisdom of legislative politics suggests that party unity in legislative voting matters for a party's brand building and ability to survive and shape policy (Carey 2007: 93). Given that party unity is crucial for the legislative process and party survival, why do some parties exhibit higher levels of party unity than others? Empirical studies have shown that variation in party unity can be explained by country-level factors such as the design of constitutional systems (Persson and Tabellini 2003), federalism (Mainwaring 1999), and electoral institutions (Hix 2004). At the party level, Ceron (2015) finds that greater intra-party division of policy preferences further decreases the level of party unity in roll-call votes when whipping resources at the leader's disposal are weak. Focusing on legislative voting in the European Parliament, Hix et al. (2005) demonstrate that a larger party group tends to have a more unified voting behavior, while a smaller party group has a lower level of party unity.

Studies have also demonstrated that a party tends to have more unified voting patterns in the legislature when it controls the executive branch (Diermeier and Feddersen 1998; Ceron 2015). Carey (2007) shows that, compared to parliamentary systems, the vote unity of governing parties tends to be lower in presidential systems. While these studies suggest that the governing status of a party matters for explaining party unity, one important research question remained unanswered: why are some governing parties more unified than other governing parties? Addressing this question matters for presidential democracies in particular, because the separation of executive and legislative powers produces an organizational dilemma. As Samuels and Shugart (2010: 38) contend, even if a party controls the executive and a majority in the legislature, the president might need to negotiate with copartisans in the legislature if the president's policy stand differs from the party's stand.

This paper aims to fill the empirical gap about the party unity of governing parties by examining the case of Mexico. Based on the theoretical perspective about the psychological component of the president's influence over the executive-legislative relations, we argue that presidential popularity matters for explaining party unity of governing parties in legislative voting. Our empirical analysis suggests that the level of vote unity of the governing party's legislators tends to increase with a higher level of presidential popularity.

This paper will proceed as follows. The second section discusses the existing literature on relations between the presidents and their affiliated parties in Mexico. Next, we propose our theory about presidential popularity and governing party unity and generate a testable hypothesis for our analysis. The fourth section discusses our research design for the quantitative analyses. Using roll-call vote data of the governing party's deputies in votes for executive-sponsored bills, the fifth section provides analyses about the impact of presidential approval rating on the level of governing party unity. The sixth section concludes. 


\section{EXISTING EXPLANATIONS OF PRESIDENT-RULING PARTY RELATIONS IN MEXICO}

Previous literature suggests that party unity in legislative voting is driven by two distinct sources (Bowler et al. 1999; Carey 2007: 93; Ceron 2015: 247). The first is cohesion (or cohesiveness), indicating the extent to which the copartisans have the same policy or ideological preferences. The second is discipline, indicating the number of whipping resources that the party leader can use to reward loyal partisans or sanction potential rebels. The PRI and its predecessors ${ }^{1}$ had dominated Mexican politics by controlling the presidency and holding majorities of both chambers of the Congress from 1934 to 1997. Many studies have shown that the PRI legislators had been highly unified in legislative voting due to the party's high levels of cohesion and discipline (Valencia Escamilla 2004; Díaz Gómez 2005; Gónzalez Tule 2010). ${ }^{2}$

What explains the extremely high levels of party unity in Mexico? Some previous studies have argued that the authoritarian orientation within Mexican political culture shaped the unbalanced relationship between the executive and legislative branches (González Casanova 1982: 32-35; Meyer Cosío 1996: 21). Other scholars focus on the impact of political institutions, such as the party-centered electoral system, the ban on reelection, and the centralized candidate nomination procedure (Casar 2002; Weldon 2004b; Langston 2006). First, before 2015, all candidates for senator or deputy in Mexico required official nomination from a party. This rule empowers political parties to control candidates' campaigns in elections. Second, the Constitution stipulates a ban on immediate reelection of senators and deputies (Nacif 2002: 258-261), and this rule had been in place between 1933 and 2018 (Político 2017). When politicians are not allowed to run for immediate reelection, they lack incentives to cultivate a personal vote, and they are almost not accountable to the voters. Moreover, as Weldon argues (2004b: 574-575), the purpose behind the reelection restriction was to undermine the connections between local political bosses and the federal legislators that they supported, so that these legislators' loyalties could be redirected to the party leader (Weldon 2003).

In addition to the party-centered electoral system and the ban on reelection, the centralized candidate nomination system makes it easier for party leaders to maintain party discipline (Langston 2008: 148). For the case of the PRI, its formal internal party organizations for candidate selection include the political council and a closed national convention; however, it is the National Executive Committee (CEN) that has the authority to decide the method for candidate selection, and the head of the CEN was designated by the president (Casar

\footnotetext{
The National Revolution Party (PNR, 1929-38) and the Mexican Revolutionary Party (PRM, 1938-1946). From 1940 to 1964, the passage rates of executive-sponsored bills in the Chamber of Deputies ranged from $95 \%$ to $100 \%$ (Weldon 2004a: 137). The extremely high rate of legislative passage of executive initiatives remained largely unchanged during the Salinas administration (1988-1994). Of the 169 executive-sponsored proposals, 164 were approved by the Chamber of Deputies (Casar 2002: 128).
} 
2002: 140-141). In addition to selecting candidates, the PRI national party organizations also have control over candidates' campaign financing (Langston 2008:146). From 1937 to 2000, the Mexican presidents were the de facto leader of the PRI (Weldon 2004b: 575), and they "acted as an arbiter among various interests within the party when nominations were decided for federal deputies" (Langston 2001: 490). In short, the presidents have used the institutions as strategic tools in the bargaining game of exchange with the legislators (Moe and Howell 1999). As a result, most legislators had to be highly disciplined in their votes on the floor, or otherwise they would risk their political career after their terms end.

\section{PRESIDENTIAL POPULARITY AND THE PRESIDENT'S PARTY UNITY IN LEGISLATIVE VOTING}

The previous discussion suggests that the party-centered electoral system, the ban on reelection, and the centralized candidate nomination procedure might shape the high levels of governing party vote unity in Mexico. However, because these three institutions had remained intact for decades, they might not help explain the variation in party unity over time. In table 1, we compare party unity scores and the numbers of executive-sponsored bills during different periods. Our calculation of the average party unity scores (see below for details) for the administrations of Ernesto Zedillo (1998-2000), Vicente Fox (2000-2006), Felipe Calderón (2006-2012), and Enrique Peña-Nieto (2012-2018) are $87.08 \%, 83.15 \%, 75.70 \%$, and $83.46 \%$, respectively. The statistical results of pairwise comparisons of means with equal variances indicate that the difference in party unity scores are statistically significant for the pairs of Zedillo and Calderón ( $\mathrm{p}<0.001)$, Fox and Calderón $(\mathrm{p}=0.002)$, and Peña-Nieto and Calderón $(\mathrm{p}=0.001)$. Clearly, explaining the variation in vote unity of the governing party requires more scrutiny.

Table 1. Executive-Sponsored Bills and Vote Unity of Governing Parties in the Mexican Chamber of Deputies (1998-2018)

\begin{tabular}{lcccc}
\hline Administration & Zedillo & Fox & Calderón & Peña-Nieto \\
\hline Legislature & $57^{\text {th }}$ & $58^{\text {th }}$ and $59^{\text {th }}$ & $60^{\text {th }}$ and $61^{\text {st }}$ & $62^{\text {nd }}$ and $63^{\text {rd }}$ \\
$\begin{array}{l}\text { Number of Executive-Sponsored Bills that } \\
\text { Were Sent to the Floor for Vote }\end{array}$ & 28 & 81 & 62 & 82 \\
$\begin{array}{l}\text { Average Party Unity Scores of Govern- } \\
\text { ing Party's Deputies in a Vote for Execu- }\end{array}$ & $87.08 \%$ & $83.15 \%$ & $75.70 \%$ & $83.46 \%$ \\
$\begin{array}{l}\text { tive-Sponsored Bills* } \\
\text { Standard Deviation of Party Unity Scores }\end{array}$ & $11.28 \%$ & $10.88 \%$ & $13.98 \%$ & $12.53 \%$ \\
\hline
\end{tabular}

*Because the roll-call vote data in Mexico were made available only from 1998, the data for the Zedillo administration in our analysis are collected for the period from November 1998 through April 2000. For the Zedillo and Peña Nieto administrations we analyzed the PRI party unity scores, and for the Fox and Calderón administrations we analyzed the PAN party unity scores.

Source: SIL (2019); authors. 
In this paper, we argue that the popularity of party leadership is a crucial factor for understanding the changing patterns of the president's party unity in legislative voting. The causal mechanism suggests that a higher level of presidential approval is a strong psychological component in executive-legislative relations, which is seen as the president's "power to persuade" (Neustadt 1960). Specifically, the president can use his prestige as a political capital to influence legislators' behavior (Edwards 1976). High public approval ratings increase the president's bargaining power in executive-legislative relations and allow the president to keep his policy position when there are changes in the preference structure of the legislature (e.g., due to a midterm election) because he can claim that he legitimately represents the preferences of "the people" (Arnold et al. 2017). Presidential approval might be perceived as a proxy for voter preferences by the legislators, and thus the legislators make a strategic decision in voting for executive-sponsored bills out of concern for being punished or rewarded by voters (Jones et al. 2002). Studies have shown that presidential popularity is positively correlated with presidential legislative success in the United States (Rivers and Rose 1985; Canes-Wrone and de Marchi 2002) and in Latin America (Alemán and Calvo 2008; Arnold et al. 2017).

Given that many studies have suggested that highly popular presidents are more likely to get their legislative initiatives approved, it makes sense to infer that most legislators from the incumbent party tend to support presidential initiatives. Previous studies based on evidence from the United States have demonstrated that the electoral fates of incumbent party legislators are intertwined with the president's popularity (Abramowitz 1985; Gronke, Koch, and Wilson 2003). Assuming that legislators are motivated by seeking to win reelection (Mayhew 1974), Lebo and O'Geen (2011) find that the president's copartisans tend to side with the president's agenda to bolster the collective reputation of the incumbent party and thus enhance the probability of being reelected. Bond and Fleisher (1990) find that the president's popularity increases his fellow partisans' support for presidential initiatives but decreases support from opposition legislators.

It seems that the "reelection seeking" assumption in the abovementioned literature on U.S. executive-legislative relations does not apply for countries like Mexico, where immediate reelection of legislators is restricted. However, if the logic behind "reelection seeking" is understood as prolonging politicians' political survival, it makes sense to infer that presidential popularity matters for understanding the political behavior of incumbent party legislators in Mexico. As Álvarez (2013: 299) points out, when politicians have no incentives for reelection, they break linkages with constituencies right after they are elected. Therefore, the PRI legislators' political survival is largely determined by party leaders, who have the power to designate jobs in non-elective offices for legislators after their terms end (Álvarez 2013: 299). These non-elective jobs include bureaucratic posts at different tiers of the party, namely, the party's national organization, local branches, party organization in the legislature, and party organization in the administration (Casar 2002: 137). Moreover, some of 
the politicians might be nominated to run for an elective office at a different level. To prolong their political career, many legislators make great efforts to pursue better relations with high-ranking party officials (Caballero-Sosa 2013: 179-181). Some other legislators would try to propose as many legislative bills as possible to attract the attention of party leaders (Béjar Algazi 2012: 622).

Based on the reason about political survival, we expect that, when a president receives high levels of popular support, the president tends to exert stronger influence on their copartisans in the legislature to support the president's policy agenda. The president's copartisans are more likely to side with the president's agenda because these copartisans expect this popular president to be more capable of helping them pursue a better career path after the legislative term ends. Moreover, supporting a popular president to achieve legislative victories helps produce an image of a united party, which can enhance the party's electoral competitiveness. Although this expected consequence has nothing to do with the electoral fortune of being reelected (because of the reelection restriction), it could help the party maintain or gain majority status in the legislature and thus gain more state resources to strengthen the party organization, which in turn could help the legislators prolong their political survival.

In contrast, an unpopular party leadership exerts less influence on copartisans in the legislature. An unpopular president might face more challenges within his party. Supporting the president's agenda might still be a necessary condition for legislators to advance their political careers after their terms end, but such advancement might not be as good as expected. Some incumbent party legislators might even make strategic decisions in voting against executive-sponsored bills facing greater intra-party power struggles. Therefore, when the president is unpopular, the level of incumbent party unity in legislative voting tends to be lower because the president is likely to be challenged by copartisans with different interests and opinions.

The discussion above suggests that the level of presidential popularity matters for the incumbent party unity even in the context where reelection is restricted. Accordingly, we generate a testable hypothesis: the level of incumbent party unity in legislative voting increases with a higher level of popular support for the president.

\section{RESEARCH DESIGN}

To test our hypothesis regarding the relationship between presidential popularity and governing party unity in legislative voting, we use the quantitative evidence of the roll-call votes in executive-sponsored bills under most of the second half of the Zedillo administration (1998-2000), the Fox administration (2000-2006), the Calderón administration (2006-2012), and the Peña-Nieto administration (2012-2018). Official roll-call vote data in the Mexican Chamber of Deputies were made available from 1998 (SIL 2019). Therefore, the data for the 
first four months of the $57^{\text {th }}$ Congress (September $1^{\text {st }}$ to December $31^{\text {st }}$ in 1997) are missing.

The unit of analysis is an executive-sponsored bill that was sent to the floor of the Chamber of Deputies. ${ }^{3}$ The main dependent variable is the level of party unity. We proposed a measure of party unity score based on the Agreement Index (AI) (Hix et al. 2005). While the AI only considers the vote options of "Yes", "No," and "Abstain", our party unity score considers "Absence" as the fourth option. In the context of Italy, absences in roll-call votes suggest some dissent within party positions (Ceron 2015: 249). We believe that it is also true for roll-call votes in Mexico. ${ }^{4}$ Our party unity score is measured through the following equation:

$$
\text { Party Unity Score } e_{i}=\frac{\max \left\{Y_{i}, N_{i}, A_{i}, H_{i}\right\}-\frac{1}{3}\left(Y_{i}+N_{i}+A_{i}+H_{i}-\max \left\{Y_{i}, N_{i}, A_{i}, H_{i}\right\}\right)}{Y_{i}+N_{i}+A_{i}+H_{i}}
$$

where $Y_{i}$ denotes the number of Yes votes expressed by party $\mathrm{i}, N_{i}$ the number of No votes, $A_{i}$ the number of Abstain votes, and $H_{i}$ the number of the party's deputies coded absent. As a result, the party unity score equals 1 when all the deputies of a party have the same voting behavior, which could be Yes, No, Abstain, or Absence. The score equals 0 when equally divided between all four of these voting options, which means that 25\% deputies voted Yes, 25\% deputies voted No, 25\% deputies abstained, and 25\% deputies did not attend the session, then the party unity score is 0 . For our analysis, we calculate party unity scores for the president's party/coalition ${ }^{5}$ in roll-call votes for executive-sponsored bills from 1998 through 2018.

Our independent variable is the level of popularity of the presidents, which is measured by presidential approval rate for the previous month. This independent variable is lagged to ensure that the dependent variable does not influence

One reviewer suggests that estimating vote unity without considering the likelihood of the bills being sent to the floor in the first place could lead to biased estimates and potentially erroneous inferences. Therefore, we collected additional data for executive-sponsored proposals that were never sent to the floor for vote. We utilize the Heckman two-stage procedure first to estimate a model predicting whether an executive-sponsored bill is sent to the floor or not, and then correct for this selection bias in our model evaluating vote unity of the governing party. In the first stage, we include committee dummies and administration dummies. The results of the Heckman selection model show that our hypothesis is supported. However, the likelihood-ratio test of independent equations is statistically insignificant (Prob > chi2 $=0.321$ ) (see the online appendix for the results). This statistic indicates that selection bias is not a serious concern, and thus the OLS model is preferred to the Heckman selection model for our data.

4 In Mexico, deputies who attended the session were allowed to do nothing in the roll-call votes. Since Congress started using an electronic voting board in 1998, deputies have had the choice to press the buttons for Yes, No, and Abstain. However, deputies can choose to not press any of these buttons during roll-call votes. In this situation, the vote counting system registers those deputies under "Quorum," which means that they only attended the session to make a quorum possible, but refrained from voting aye, nay, or abstain. While this kind of behavior might be less "controversial" than simply pressing the abstain button, we believe that its consequence is identical to abstention.

5 The PRI secured the majority in the Chamber of Deputies during the Peña-Nieto administration by allying with the Green Party (PVEM) and the New Alliance Party (PANAL). Therefore, we measure our dependent variable by taking into account the PRI, PVEM, and PANAL in the governing coalition. 
the independent variable. We use the data from ORACULUS (Márquez 2019), which provides estimated presidential approval rates for each month beginning from January 1995 until now. The estimated presidential approval rates were calculated using an aggregation method that consists of a Bayesian multinomial model on major public opinion polls of presidential approval rates in Mexico. ${ }^{6}$ In our dataset, there are 253 executive-sponsored bills with available data for party unity scores. However, because some votes for executive-sponsored bills took place in the first month of a new administration, the lagged presidential approval rate is not available, which reduces the total number of observations to 239 .

In the empirical model, we include a number of control variables. First, we control for the size of the governing party, measured as the percentage of seats secured by the president's party/coalition in the Chamber of Deputies. Previous studies have shown that the majority party's vote unity decreases when the party secures more seats (Ricker 1962) because it is more difficult for larger parties to keep their fellow partisans in line with the party's direction than smaller parties would (Volden and Bergman 2006: 91). However, Hix et al. (2005) demonstrate that a large party will have a higher level of party unity because its copartisans tend to be unified for influencing policy outcomes when there is more at stake in votes. Therefore, it might be necessary to control for the potential impact of party size on party unity.

In addition, we control for the "honeymoon" period and the "lameduck" period, operationalized as the first twelve months after the new president assumed office and the last twelve months before the end of the term, respectively. Studies have shown that the newly inaugurated president is more likely to achieve greater legislative success during the honeymoon period because of the recent mandate from the voters (Molinas et al. 2004; Alemán and Navia 2009). The effect of the lame duck period suggests that the president's power to persuade tends to fade away as the mandate from the voters is about to renew due to the upcoming election (Light 1999; Barrett and Eshbaugh-Soha 2007). Therefore, we control for these two variables in our models because it is possible that legislators of the governing party might be more unified in legislative voting during the honeymoon period and less unified during the lame duck period.

Furthermore, we include the policy areas that each executive-sponsored bill belongs to ${ }^{7}$ for considering the possibility that the level of governing party's vote unity might be higher for bills of certain policy areas than others. In our empirical model, we include dummy variables for constitutional reforms, public finance, education, labor and social welfare, energy and environment, econom-

See https://oraculus.mx/aprobacion-presidencial/\#metodologia for details.

For our period of study, we identified the names of more than sixty committees in Mexican Chamber of Deputies. Some of them were separated into different committees from one Congress to the other, and others merged into a single committee. See the online appendix for how we categorized each committee to a particular policy area. 
ic development, and human rights and political reforms, with the category of "others" as the reference group. Our categorization largely follows Alemán and Navia's (2009) categorization, and we add some policy areas that are specific to Mexico's context. In addition to the policy area variables mentioned above, we also control for a dummy variable for "joint committees." This variable is coded 1 when the proposal was sent to multiple committees for joint review and decision, and 0 otherwise. It is expected that party unity tends to be lower in a vote for a bill with multiple committee referrals (Davidson et al. 1988).

In our model, we also control for several variables that could possibly affect governing party's vote unity. We include GDP growth lagged by one quarter (INEGI 2020) and crime growth rate lagged by one month (SNSP 2019). Moreover, to control for the possibility that the governing parties might have higher vote unity in some administrations but not others, we control for dummy variables for Fox, Calderón, and Peña-Nieto administrations, using the Zedillo administration as the reference group. Last, we include the first lag of the dependent variable ${ }^{8}$ as a control to consider any potential serial correlation of errors. Table 2 reports descriptive statistics for the variables used in our empirical analyses.

Table 2. Descriptive statistics.

\begin{tabular}{lccccc}
\hline & $\begin{array}{c}\text { Number of } \\
\text { Observations }\end{array}$ & Mean & $\begin{array}{c}\text { Standard } \\
\text { Deviation }\end{array}$ & $\begin{array}{c}\text { Minimum } \\
\text { Value }\end{array}$ & $\begin{array}{c}\text { Maximum } \\
\text { Value }\end{array}$ \\
\hline Party Unity Score & 253 & 81.86 & 12.76 & 37.81 & 100 \\
Lagged Party Unity & 248 & 81.58 & 12.57 & 39.45 & 100 \\
Presidential Approval & 240 & 53.60 & 11.67 & 23 & 70 \\
Honeymoon Period & 253 & 0.24 & 0.43 & 0 & 1 \\
Lame Duck Period & 253 & 0.15 & 0.35 & 0 & 1 \\
Size of the Governing Party & 253 & 43.41 & 7.94 & 29.4 & 52.2 \\
Crime Growth Rate & 253 & -0.14 & 6.84 & -12.23 & 14.22 \\
GDP Growth Rate & 253 & 0.51 & 1.16 & -5.10 & 3.25 \\
Constitutional Reforms & 253 & 0.06 & 0.23 & 0 & 1 \\
Public Finance & 253 & 0.67 & 0.47 & 0 & 1 \\
Education & 253 & 0.02 & 0.12 & 0 & 1 \\
Labor and Social Welfare & 253 & 0.04 & 0.20 & 0 & 1 \\
Energy and Environment & 253 & 0.04 & 0.19 & 0 & 1 \\
Economic Development & 253 & 0.06 & 0.24 & 0 & 1 \\
Human Rights and Political Reforms & 253 & 0.02 & 0.14 & 0 & 1 \\
Joint Committees & 253 & 0.17 & 0.37 & 0 & 1 \\
Zedillo & 253 & 0.11 & 0.31 & 0 & 1 \\
Fox & 253 & 0.32 & 0.47 & 0 & 1 \\
Calderón & 253 & 0.25 & 0.43 & 0 & 1 \\
Peña-Nieto & 253 & 0.32 & 0.47 & 0 & 1 \\
\hline
\end{tabular}

Source: Authors. 


\section{EXPLAINING THE DYNAMICS OF VOTE UNITY OF THE GOVERNING PARTY}

Table 3 presents the results of ordinary least squares (OLS) regression models ${ }^{9}$ on governing party's vote unity for executive-sponsored bills. Model 1 includes the independent variable and control variables except for administration dummies, while Model 2 is the full model that includes the independent variable and all control variables. As can be seen, presidential popularity has a positive and statistically significant coefficient in both Model 1 and Model 2. The finding in Model 1 suggests that a one percentage point increase in presidential approval rate is associated with a 0.27 percentage point increase in the party unity score of the governing party, while the finding in Model 2 suggests that a one percentage point increase in presidential approval rate is associated with a 0.38 percentage point increase in the party unity score.

Substantively, based on the results of Model 1, holding other variables constant, when the presidential approval rate is at a low level (one standard deviation below the mean), the predicted party unity score is 78 percentage points. In contrast, when the presidential approval rate is at a high level (one standard deviation above the mean), the predicted party unity score is 85 percentage points..$^{10}$ Overall, the evidence presented here supports our main hypothesis, suggesting that incumbent party legislators are more likely to vote in the same direction for executive-sponsored bills when presidential popularity is high.

Table 3. Vote Unity of Governing Parties for Executive-Sponsored Proposals (1998-2018)

\begin{tabular}{lcc}
\hline Variable & Model 1 & Model 2 \\
\hline Presidential Approval & $0.270^{* * *}$ & $0.379^{* *}$ \\
& $(0.084)$ & $(0.179)$ \\
Honeymoon Period & -0.193 & 0.082 \\
& $(2.068)$ & $(3.402)$ \\
Lame Duck Period & $-8.418^{* * *}$ & $-9.965^{* * *}$ \\
& $(2.612)$ & $(2.804)$ \\
Size of the Governing Party & $0.515^{* * *}$ & 0.256 \\
& $(0.129)$ & $(0.160)$ \\
Crime Growth Rate & $-0.481^{* * *}$ & $-0.466^{* * *}$ \\
& $(0.099)$ & $(0.107)$ \\
GDP Growth Rate & $1.950^{* * *}$ & $1.783^{* * *}$ \\
& $(0.481)$ & $(0.532)$ \\
Constitutional Reforms & 0.748 & 2.071 \\
& $(2.476)$ & $(2.399)$ \\
Public Finance & $6.315^{* * *}$ & $6.135^{* * *}$ \\
& $(1.651)$ & $(1.663)$ \\
\hline
\end{tabular}

Because the party unity scores range from 0 to 100 percentage points, we also estimated a fractional logit model as a robustness check. The results are similar to the results of Model 2. 


\begin{tabular}{lcc}
\hline Variable & Model 1 & Model 2 \\
\hline Education & $9.254^{* * *}$ & $8.004^{* * *}$ \\
& $(3.246)$ & $(2.816)$ \\
Labor and Social Welfare & -0.279 & 0.845 \\
& $(2.496)$ & $(2.646)$ \\
Energy and Environment & $3.856^{*}$ & $3.987^{*}$ \\
& $(2.135)$ & $(2.361)$ \\
Economic Development & -4.853 & -3.607 \\
Human Rights and Political & $(3.776)$ & $(3.370)$ \\
forms & $6.224^{* *}$ & $6.131^{* * *}$ \\
Joint Committees & $(2.526)$ & $(2.108)$ \\
& -0.270 & -1.082 \\
Lagged Party Unity & $(1.662)$ & $(1.575)$ \\
& 0.110 & 0.026 \\
Fox & $(0.071)$ & $(0.079)$ \\
& - & -2.637 \\
Calderón & - & $(2.743)$ \\
Peña-Nieto & - & $-9.684^{* * *}$ \\
Constant & - & $(3.540)$ \\
R-squared & $31.866^{* * *}$ & 0.813 \\
Number of observations & $(8.776)$ & $(4.987)$ \\
\hline
\end{tabular}

${ }^{* * *} \mathrm{p} \leq 0.01,{ }^{* *} \mathrm{p} \leq 0.05,{ }^{*} \mathrm{p} \leq 0.1$ (two-tailed tests). Entries are OLS regression coefficients with robust standard errors in parentheses.

Source: Authors.

For the control variables, the coefficient for lame duck period is negative and statistically significant in both models. This finding suggests that president's copartisans are less likely to side with presidential proposals when the term is approaching to the end. In contrast, the coefficient for honeymoon period is not statistically significant in either model. Regarding the results about the contextual variables, the coefficient of crime growth rate is negative and statistically significant, indicating that the level of governing party's vote unity tends to be lower when the number of crime incidents increases compared to the previous month. Moreover, the positive and statistically significant coefficient of GDP growth suggests that president's copartisans tend to vote in line with the party's direction when the economy performance improves.

The coefficient for the incumbent party size is positive and statistically significant for Model 1, suggesting that a larger governing party tends to be more unified in vote for executive-sponsored bills. The coefficient of this variable is also positive in Model 2, but it does not reach statistical significance at $\mathrm{p}<0.05$ level. Regarding the administration-specific effects on vote unity, the finding indicates that the governing party's vote unity was lower in the Calderón administration, compared to that in the Zedillo administration. However, the 
coefficients for the Fox administration and the Peña-Nieto administration are statistically insignificant.

Table 3 also demonstrates interesting results about policy area variables. For instance, the coefficients for public finance, education, energy and environment, and human rights and political reforms are positive and statistically significant, suggesting that the level of governing party's unity tends to be higher in votes for executive-sponsored bills in these policy areas, compared to bills in the omitted category. In contrast, the coefficients for the policy area variables of economic development, constitutional reform, and labor and social welfare do not achieve statistical significance. The coefficient of joint committee is negative, suggesting that the president's copartisans might be less likely to vote in line with the incumbent party's direction; however, the coefficient is statistically insignificant.

To check the robustness of our results, we have conducted a number of sensitivity tests (see Table 4). First, to ensure that our results are not sensitive to coding decisions for the independent variable, we used an alternative measure that is calculated by subtracting disapproval rate from approval rate. The re-estimated results in Model 3 remain largely unchanged. Second, to ensure that our results are not driven by the choice of party unity measures, we replaced our dependent variable of party unity score with the Rice Index and re-estimate our model. The Rice Index is measured as the absolute value of the difference in the percentage of AYE votes from the party and the percentage of NAY votes from the party. ${ }^{11}$ The re-estimated results in Model 4 show that the coefficient of presidential approval is positive and statistically significant.

Table 4. Robustness Tests

\begin{tabular}{lcccc}
\hline & & Model 4 & \multicolumn{2}{c}{ Model 5 (2SLS) } \\
\cline { 4 - 5 } Variable & Model 3 & $\begin{array}{c}\text { (DV = Rice } \\
\text { Index) }\end{array}$ & $\begin{array}{c}\text { First Stage } \\
\text { (DV }= \\
\text { Approval) }\end{array}$ & $\begin{array}{c}\text { Instrumental } \\
\text { Variable } \\
\text { Regression }\end{array}$ \\
\hline \multirow{2}{*}{ Approval - Disapproval } & $0.139^{* * *}$ & - & - & - \\
Presidential Approval & $(0.040)$ & - & - & $0.490^{* * *}$ \\
& - & $0.201^{* * *}$ & - & $(0.135)$ \\
Logged Number of Crime Incidents & - & - & $-53.673^{* * *}$ & - \\
Honeymoon Period & -0.557 & -0.074 & $14.456^{* * *}$ & -2.276 \\
& $(2.094)$ & $(1.551)$ & $(1.072)$ & $(2.234)$ \\
Lame Duck Period & $-8.359^{* * *}$ & $-6.197^{* * *}$ & 0.486 & $-8.493^{* * *}$ \\
Size of the Governing Party & $(2.615)$ & $(1.964)$ & $(1.609)$ & $(2.572)$ \\
& $0.535^{* * *}$ & $0.391^{* * *}$ & $-0.820^{* * *}$ & $0.710^{* * *}$ \\
& $(0.131)$ & $(0.099)$ & $(0.078)$ & $(0.162)$ \\
\hline
\end{tabular}




\begin{tabular}{|c|c|c|c|c|}
\hline \multirow[b]{2}{*}{ Variable } & \multirow[b]{2}{*}{ Model 3} & \multirow{2}{*}{$\begin{array}{c}\text { Model } 4 \\
\text { (DV = Rice } \\
\text { Index) }\end{array}$} & \multicolumn{2}{|c|}{ Model 5 (2SLS) } \\
\hline & & & $\begin{array}{c}\text { First Stage } \\
(\mathrm{DV}= \\
\text { Approval) }\end{array}$ & $\begin{array}{l}\text { Instrumental } \\
\text { Variable } \\
\text { Regression }\end{array}$ \\
\hline Crime Growth Rate & $\begin{array}{c}-0.483^{* * *} \\
(0.099)\end{array}$ & $\begin{array}{c}-0.352^{* * *} \\
(0.074)\end{array}$ & $\begin{array}{c}0.005 \\
(0.075)\end{array}$ & $\begin{array}{c}-0.460^{* * *} \\
(0.103)\end{array}$ \\
\hline GDP Growth Rate & $\begin{array}{c}2.014^{* * *} \\
(0.484)\end{array}$ & $\begin{array}{c}1.470^{* * *} \\
(0.362)\end{array}$ & $\begin{array}{l}-1.137^{* *} \\
(0.562)\end{array}$ & $\begin{array}{c}2.291^{* * *} \\
(0.515)\end{array}$ \\
\hline Constitutional Reforms & $\begin{array}{l}0.855 \\
(2.418)\end{array}$ & $\begin{array}{c}0.601 \\
(1.854)\end{array}$ & $\begin{array}{l}-3.613 \\
(2.397)\end{array}$ & $\begin{array}{l}2.413 \\
(2.539)\end{array}$ \\
\hline Public Finance & $\begin{array}{c}6.321^{* * *} \\
(1.640)\end{array}$ & $\begin{array}{l}4.608^{* * *} \\
(1.243)\end{array}$ & $\begin{array}{l}-0.331 \\
(1.303)\end{array}$ & $\begin{array}{c}6.389^{* * *} \\
(1.639)\end{array}$ \\
\hline Education & $\begin{array}{l}9.336^{* * *} \\
(3.291)\end{array}$ & $\begin{array}{c}6.961^{* * *} \\
(2.422)\end{array}$ & $\begin{array}{l}-0.147 \\
(2.160)\end{array}$ & $\begin{array}{c}10.162^{* * *} \\
(3.189)\end{array}$ \\
\hline Labor and Social Welfare & $\begin{array}{l}-0.342 \\
(2.470)\end{array}$ & $\begin{array}{c}-0.193 \\
(1.871)\end{array}$ & $\begin{array}{l}-0.822 \\
(2.458)\end{array}$ & $\begin{array}{c}0.362 \\
(2.331)\end{array}$ \\
\hline Energy and Environment & $\begin{array}{l}3.746^{*} \\
(2.138)\end{array}$ & $\begin{array}{l}3.015^{*} \\
(1.604)\end{array}$ & $\begin{array}{c}0.954 \\
(2.726)\end{array}$ & $\begin{array}{l}4.219^{* * *} \\
(2.102)\end{array}$ \\
\hline Economic Development & $\begin{array}{l}-4.852 \\
(3.749)\end{array}$ & $\begin{array}{l}-3.571 \\
(2.833)\end{array}$ & $\begin{array}{l}-3.212 \\
(2.198)\end{array}$ & $\begin{array}{l}-3.870 \\
(3.611)\end{array}$ \\
\hline $\begin{array}{l}\text { Human Rights and Political Re- } \\
\text { forms }\end{array}$ & $\begin{array}{l}5.879 * * \\
(2.431)\end{array}$ & $\begin{array}{l}4.668^{* *} \\
(1.886)\end{array}$ & $\begin{array}{l}2.435 \\
(2.049)\end{array}$ & $\begin{array}{l}4.798^{*} \\
(2.506)\end{array}$ \\
\hline Joint Committees & $\begin{array}{l}-0.209 \\
(1.657)\end{array}$ & $\begin{array}{c}-0.102 \\
(1.248)\end{array}$ & $\begin{array}{c}1.631 \\
(1.449)\end{array}$ & $\begin{array}{l}-0.758 \\
(1.749)\end{array}$ \\
\hline Lagged Party Unity & $\begin{array}{c}0.102 \\
(0.072)\end{array}$ & $\begin{array}{c}0.104 \\
(0.072)\end{array}$ & $\begin{array}{l}-0.037 \\
(0.051)\end{array}$ & $\begin{array}{c}0.082 \\
(0.074)\end{array}$ \\
\hline Constant & $\begin{array}{l}44.092 \\
(6.395)\end{array}$ & $\begin{array}{c}46.437^{* * *} \\
(7.398)\end{array}$ & $\begin{array}{c}721.301^{* * *} \\
(52.958)\end{array}$ & $\begin{array}{c}14.041 \\
(11.778)\end{array}$ \\
\hline R-squared & 0.382 & 0.366 & 0.645 & 0.355 \\
\hline Number of observations & 239 & 239 & 239 & 239 \\
\hline
\end{tabular}

${ }^{* * *} \mathrm{p} \leq 0.01,{ }^{* *} \mathrm{p} \leq 0.05,{ }^{*} \mathrm{p} \leq 0.1$ (two-tailed tests). Entries are OLS regression coefficients with robust standard errors in parentheses.

Source: Authors.

So far, the models that have been estimated do not consider possible endogeneity between presidential approval rates and the vote unity of legislators from the governing party. It is possible that a certain latent variable might affect both presidential approval and incumbent party unity in legislative voting. Without considering this latent variable, our OLS results might be flawed. A stronger test of the causal order between presidential approval and incumbent party unity can be performed by using instrumental variable regression. For our purposes, a valid instrument should be a good predictor of presidential approval but should have no direct effect on the governing party's vote unity. In our dataset, we find that the monthly number of crime incidents (logged) (SNSP 2019) would be a good instrument.

We used the instrumental variable approach to re-estimate the equations of Model 1. Results of the two-stage least squared (2SLS) regression in Model 5 indicate that the selection is not driven by our main finding: the presidential approval coefficient is positive and statistically significant at the $p<0.01$ lev- 
el. The Montiel-Pflueger robust weak instrument test shows that the effective F-statistic is 142.83 , and the critical values for a tolerance threshold of worstcase bias $\tau \in\{5 \%, 10 \%, 20 \%, 30 \%\}$ are $[37.42,23.11,15.06,12.04]$, respectively. ${ }^{12}$ The test rejects the null that the IV is weak if we tolerate the bias up to a $5 \%$ worst-case bias level. In short, the results of the instrumental variable approach mirror those reported earlier. Overall, we are confident that our findings are robust to a number of sensitivity tests and to controlling for potential endogeneity among our variables.

\section{A Case Study of the Peña-Nieto Administration}

To further illustrate the theoretical mechanism about how presidential popularity affects incumbent party unity, we provide a brief case study of relations between the president's popularity and governing party unity under the Peña-Nieto administration (2012-2018). Different from the pre-2000 era, and lacking a unity figure traditionally embodied by the President of the Republic, the PRI went through a difficult process to maintain its cohesion from 2000 through 2012 (Langston 2019). The wounds left by the loss of the presidency in 2000 prompted a reorganization where the opposing factions to former president Zedillo prevailed and supported the election of Roberto Madrazo, former governor of Tabasco, as the new head of the PRI. Nevertheless, acting as the president of the PRI, Madrazo had to face constant challenges by state governors who also started to concentrate more decision power and were interested in gaining nationwide projection, keeping in mind their future political careers (Hernández Rodríguez 2009: 32-33).

The preservation of its position as the largest parliamentary group in Congress during the years of the Fox administration (2000-2006) gave a large influence to the PRI, who used it as leverage to increase the power of state governors in budgetary allocations, all in the name of strengthening federalism. As a result, governors became major figures within the party, influencing candidate-selection procedures in their states, and effectively creating factions within the PRI caucus in the Chamber of Deputies (Langston 2010: 241).

In this regard, governors also became important actors for the maintenance of party cohesion within the legislative organs (Rosas and Langston 2011; Cantú and Desposato 2012; Kerevel 2015). This increasing power of governors created frictions with Madrazo. In an attempt to put a brake on Madrazo's purpose to achieve the party's presidential nomination for the 2006 elections, some PRI governors and high-profile elements created an unofficial alliance known as TUCOM (All United Against Madrazo) (Hernández Rodríguez 2009: 35-40). The final selection of Madrazo as the PRI candidate created further tensions and

12 The Montiel-Pflueger (Montiel Olea and Pflueger 2013) test statistic and the critical values are obtained using the Stata command "weakivtest" (Pflueger and Wang 2015). 
division within the party, which resulted in the party's greatest defeat in history, being displaced to the third position, after the PAN and the PRD-PT-Convergencia coalition.

These experiences played in favor of state governors, who continued accumulating power and influence within the party during the government of Felipe Calderón (2006-2012). The party's presidency under Beatriz Paredes, herself a former state governor, was characterized by the emergence of a group of governors who became the new face of the PRI or "el Nuevo PRI." Among them, through a constant campaign in mass media, the most popular was the governor of the State of Mexico, Enrique Peña-Nieto (Gutiérrez and Cuevas 2012). In spite of the interest of other governors to win the party's nomination for the 2012 elections, especially Humberto Moreira from Coahuila, the party showed its concerns over the need to avoid a similar episode to those in 2000 and 2006. With Moreira being appeased after his election as the new president of the party, and former Sonora governor and a major figure within the party, Manlio Fabio Beltrones, giving up his intentions to seek the PRI's nomination, the different factions showed their unified support for Peña-Nieto after he proved to be the most popular candidate and the only one with a real chance to win (Gutiérrez and Cuevas 2012: 68-69).

The 2012 victory of Peña-Nieto meant not only a triumph for the factions representing state governors, but faced the party with a changed reality. After 12 years of being opposition, the PRI leadership had to decide between going back to the times when the President of the country was again the effective head of the party, or to give more room for opposing views and democratic practices. As a way to show their commitment to unity, the PRI chose traditional figures within the party - Manlio Fabio Beltrones in the Chamber of Deputies, and Emilio Gamboa Patrón in the Senate - to lead PRI members in Congress. Therefore, given the impressive results in the federal elections and the level of popularity of the President, the first half of the Peña-Nieto administration was characterized by cooperation between PRI factions (Mirón Lince 2014: 140-143). The election of César Camacho, also a former governor of the State of Mexico and considered a close ally to Peña-Nieto, as the party's president was also perceived as a vote of confidence by the different groups within the PRI and a commitment to party unity (Bertaccini 2015: 51-52).

The first big test for the PRI in Congress came with an ambitious series of constitutional reforms in areas such as telecommunications, energy, finance, electoral process, and economic competition, and Peña-Nieto made an informal strategic alliance with major opposition parties for the effective passage of those bills. The compact, known as "Pacto por México" (Pact for Mexico), allowed the executive to regain the initiative in legislative affairs (Zepeda 2017: 14-19). The PRI victory margin, combined with the appalling results of the PAN in the 2012 elections and the internal divisions within the PRD, which resulted in the defection of López Obrador, who opted for the creation of a new political party, the MORENA, made it easier for the PRI not only to maintain high levels 
of cohesion, but also to find allies in Congress for the approval of different proposals submitted by the Executive.

However, the divergence of opinions in certain areas between and within the members of the Pacto, particularly in education, energy, and taxes, and the many criticisms from pundits and other political leaders, related in part to corruption scandals unveiled since 2013, led to an abrupt end of the alliance before the final year of the $62^{\text {nd }}$ Congress. This came before the discussion and approval of the necessary bills to provide secondary legislation for the constitutional reforms derived from the Pacto. As the latter came to an end in the second half of the Peña-Nieto administration, Congress began to retake the initiative in making legislative proposals (Zepeda 2017: 28). More importantly, Peña-Nieto's popularity steadily dropped beginning from the second half of his administration (see figure 1).

Figure 1. Presidential Approval Rate and Disapproval Rate during the PeñaNieto Administration

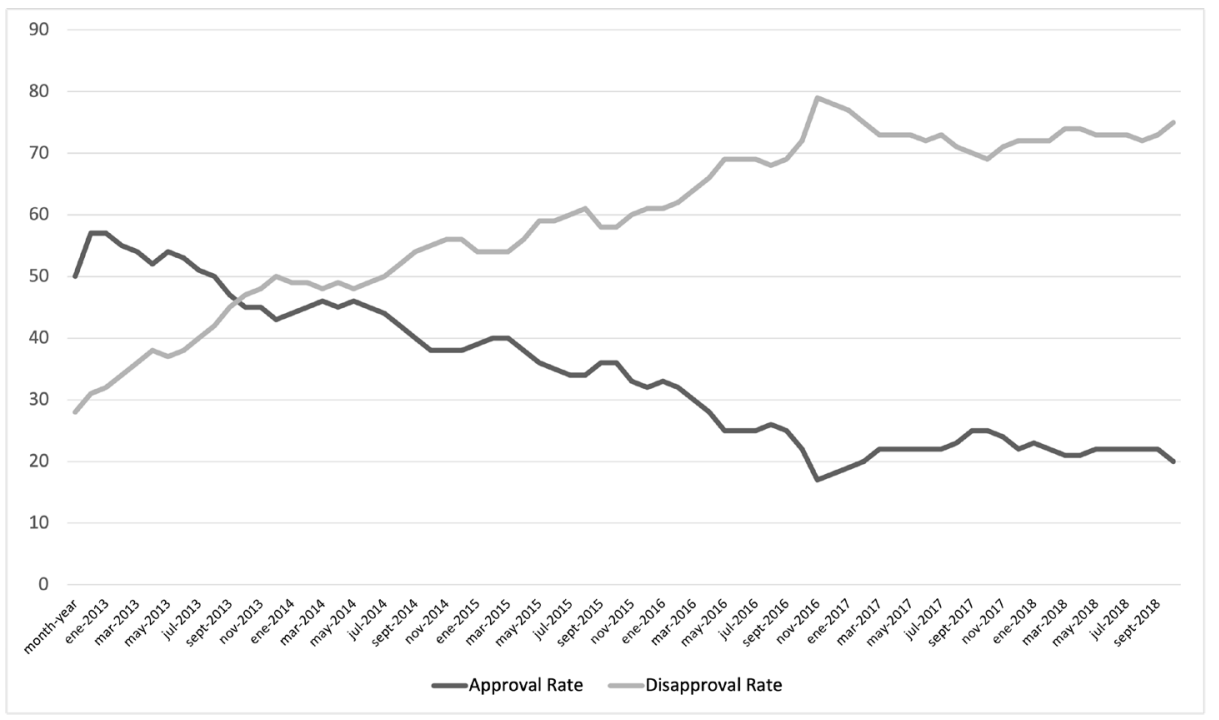

Source: Márquez (2019).

These changes also affected relations between the president of the country and the incumbent party. After the 2015 midterm elections and thinking about the incoming succession, Peña-Nieto attempted to influence the election for PRI party president, supporting his close ally Enrique Ochoa, who finally ran unopposed in 2016. Because Ochoa lacked political and electoral experience (Navarrete Vela and Espejel Espinoza 2018: 174-175), his nomination for the PRI chairmanship had been highly criticized (ANSA 2016). After assuming the PRI chairmanship, Ochoa had serious confrontations with members of the CEN, 
which had seriously undermined the identity and unity of priístas (Miranda 2018: 83). Through the 2015 elections, the PRI managed to retain the largest group in the Chamber of Deputies, though it lost many of the seats occupied during the previous Congress. The new leader of the party in the Chamber of Deputies was César Camacho, meaning that the political faction from the State of Mexico, and closely identified with Peña-Nieto, was now leading the deputies from the PRI. Nonetheless, the further attempts made by the President to continue influencing the party internal affairs were met with resistance from those traditional groups that began to be concerned with the increasing levels of unpopularity of the head of the executive.

During the $63^{\text {rd }}$ Congress, the average presidential approval rate was $25 \%$, while the average presidential disapproval rate was $69 \%$. In other words, Peña-Nieto's disapproval rate during the second half of his administration is on average 2.8 times his approval rate. The president's low level of popularity had made the legislators of the incumbent party coalition more likely to express their discontent about the party. Instead of voting against the party direction on the floor, many PRI deputies chose to take an absence during the roll-call votes. Among the 253 executive-sponsored bills in our dataset, 16 of the bills' turnout rates for incumbent party/coalition legislators were lower than $70 \%$, and 5 out of these 16 bills were voted during the $63^{\text {rd }}$ Congress.

Another important piece of evidence, although not tested empirically in the previous section, suggests that weak party leadership might make copartisans less likely to endorse executive-sponsored bills. During the $63^{\text {rd }}$ Congress, the executive sponsored 39 bills, but only 35 made it to the floor. Three proposals that died in the committee discussion stage were related to reforms seeking to legalize same-sex marriage and expand rights to gay couples. The tensions between the PRI leadership in Congress and Peña-Nieto became evident when the former never showed their support to these executive-sponsored bills, among other objections, fearing a conservative backlash in the incoming local elections in some states (Martínez Carmona 2017).

The dwindling popularity of Peña-Nieto and the road to the 2018 succession process would continue making the party division more evident. Stiffness among different factions within the PRI reached a new height when the party's nomination for the 2018 presidential candidate went to José Antonio Meade. He was not a PRI member, and had served as minister during the administrations of Calderón and Peña-Nieto. Despite the decision being justified by claiming that Meade was perceived as incorruptible and an effective administrator, those members identified with the traditional bases of the party gave a cool reception to his candidacy, given his lack of identification with the PRI, which later impacted the election results (Aragón Falomir et al. 2019). Some of them went as far as to suggest that they should 
separate the image of the party from that of unpopular president Peña-Nieto (Tamayo 2019: 27).

The failed intentions of two powerful members of the cabinet to obtain the party's nomination - Luis Videgaray, who was considered Peña-Nieto's righthand man, and Miguel Ángel Osorio Chong, a former governor of Morelos also contributed to the party's internal fractures. The inner irritation in the PRI became so alarming that Peña-Nieto agreed to a change of the party's leadership in the middle of the electoral process. As a way to show sympathy with the traditional groups, Enrique Ochoa was replaced by René Juárez, then a Senator and former governor of Guerrero, as the PRI's chairman (Miranda 2018). Nevertheless, the changes in strategy were not enough to avoid a mass defection of members who started emigrating to other parties, mainly MORENA, and a repetition of the PRI's 2006 electoral defeat, falling to the third position (Garrido and Freidenberg 2020).

One alternative explanation for the lower levels of PRI's party unity might be that the PRI's candidate nomination procedures are decentralizing. Because of the transformation of the opposition PAN and PRD into catch-all parties in the late 1990s, the PRI found itself in a debate to complete a transition from a sectoral-based party to a territorial-based party (Klesner 2005: 133-135). As it was explained above, a consequence of the PRI's support for deeper federalism is that governors have been granted more power in the party's candidate selection process (Olmeda 2009: 106). This situation might provide PRI legislators with more opportunities to strategically deviate from the party's direction when necessary.

However, previous research noted that the introduction of new methods has been far from ending the concentration of authority by the central leadership of the PRI in the candidate nomination process (Wuhs 2006: 43-45). Besides preserving the power to select candidates included in the PR deputies closed lists, the CEN has made use of an instrument known as convocatoria, customizing the rules observed during primaries and conventions in order to favor their preferred hopefuls and create the environment to select "candidates of unity" (Langston 2001: 494-495). After negotiations with governors and other factional or sectorial leaders, the authority of the CEN serves to ensure the gratitude and loyalty of those candidates towards their leadership in Congress once they are elected (Wuhs 2006: 43). As a result, the superficial changes in the candidates' nomination procedures might not help explain fully the variation in levels of party unity in the PRI.

Overall, the case study of the Peña-Nieto administration suggests that the level of popularity of the party leadership matters for the president's party unity in legislative voting. The PRI party leadership during the $63^{\text {rd }}$ Congress was not strong and was frequently challenged by copartisans. The incumbent party legislators did not necessarily vote against the party direction during the roll- 
call vote, but they might abstain from the vote to protest. Moreover, they sometimes are likely to prevent the executive-sponsored bills from being sent to the floor. The brief case study provides some evidence to support our hypothesis that a weaker party leadership might reduce the level of party unity.

\section{CONCLUSION}

This study is motivated by the lack of scholarly attention to presidential party unity. Previous research has argued that the incumbent party tends to be more unified in legislative voting, but few studies examine why some governing parties exhibit a higher level of party unity than other governing parties. We argue that a president's copartisans in the legislature tend to vote along with the party line when the president has high public approval. Using roll-call vote data in Mexican Chamber of Deputies from 1998 to 2018, the empirical results support our theoretical claim, demonstrating that the president's party unity increases with higher presidential approval rates.

Our findings carry important theoretical and substantive implications. The causal mechanism of presidential popularity and incumbent party unity is closely linked to politicians' political survival. In countries such as Mexico where reelection is restricted, higher levels of presidential approval suggests that the president would have a greater capability to help a president's copartisans' career advancement after the term ends. Legislators from the incumbent party are more likely to side with the president's legislative proposals when the president enjoys high popularity not only for showing loyalty to the president, but also for helping build a more unified image for the party, which could help the party maintain or gain majority status in the future legislative elections. Therefore, one implication of this study for presidential democracies is that presidents must maintain or increase popularity so that their legislative agenda is more likely to be supported by the copartisans.

Overall, this study contributes to the literature about party development and legislative politics in new democracies. It also creates new opportunities for a broader research agenda for party unity in legislative voting. One possible extension is to conduct comparative research of other types of government forms, such as countries with a parliamentary system, for testing the hypothesis proposed by this study. Another extension is to explore the interactive effects of presidential popularity with other institutional factors on the unity of the president's party. Last, the recent lifting of the ban on reelection in Mexico might encourage personal vote and thus provide more incentives for legislators to move away from toeing the party line in legislative voting. It is promising for future studies to address these issues for a more nuanced understanding of how presidential approval conditions legislative politics. 


\section{REFERENCES}

Abramowitz, Alan I. 1985. "Economic Conditions, Presidential Popularity, and Voting Behavior in Midterm Congressional Elections." Journal of Politics 47(1): 31-42.

Alemán, Eduardo and Ernesto Calvo. 2008. "Analyzing Legislative Success in Latin America: The Case of Argentina." In New Voices in the Study of Democracy in Latin America, edited by Guillermo O'Donnell, Joseph S. Tulchin, and Augusto Varas. Washington, D.C.: Woodrow Wilson International Center for Scholars, 7-37.

Alemán, Eduardo, and Patricio Navia. 2009. "Institutions and the Legislative Success of 'Strong' Presidents: An Analysis of Government Bills in Chile." Journal of Legislative Studies 15(4): 401-419.

Álvarez, Jorge Arturo. 2013. "Why Has the Transition to Democracy Led the Mexican Presidential System to Political Instability? A Proposal to Enhance Institutional Arrangements." Mexican Law Review 5(2): 277-304.

ANSA. 2016, 9 July. "Peña Nieto se enfrenta a una 'rebelión en la granja'." ANSA Latina. Retrieved September 22, 2019 from http:// www.ansalatina.com/americalatina/noticia/mexico/2016/07/ 09/nominacion-de-tecnocrata-en-el-pri-abre-rebelion_ce1d2ce9-b5c4-4397-839ced96934605f2.html

Aragón Falomir, Jaime, Alfredo Edmundo Fernández de Lara Gaitán, and Juan Bautista Lucca. 2019. "Las elecciones de 2018 en México y el triunfo del Movimiento de Regeneración Nacional (Morena)." Estudios Políticos (Universidad de Antioquía) 54: 286-308.

Arnold, Christian, David Doyle and Nina Wiesehomeier. 2017. "Presidents, Policy Compromise, and Legislative Success." Journal of Politics 79(2): 380-395.

Barrett, Andrew W., and Matthew Eshbaugh-Soha. 2007. "Presidential Success on the Substance of Legislation." Political Research Quarterly 60(1): 100-112.

Béjar Algazi, Luisa. 2012. “QQuién legisla en México? Descentralización y proceso legislativo." Revista Mexicana de Sociología 74(4): 619-647.

Bertaccini, Tiziana. 2015. "México y la transición inconclusa. El regreso del Partido Revolucionario Institucional." Tiempo Devorado 2(1): 40-53.

Bond, Jon R., and Richard Fleisher. 1990. The President in the Legislative Arena. Chicago: University of Chicago Press.

Bowler, Shaun, David M. Farrell, and Richard S. Katz. 1999. "Party Cohesion, Party Discipline, and Parliaments." In Party Discipline and Parliamentary Government, edited by Shaun Bowler, David M. Farrell, and Richard S. Katz. Columbus: Ohio State University Press, 3-22.

Caballero-Sosa, Lila. 2013. "Party Dynamics in the Mexican Chamber of Deputies: Power Networks and Committee Appointments." Doctoral dissertation, The London School of Economics, Retrieved July 20, 2019 from http:/ / etheses.lse.ac.uk/597/

Canes-Wrone, Brandice and Scott de Marchi. 2002. "Presidential Approval and Legislative Success." Journal of Politics 64(2): 491-509.

Cantú, Francisco and Scott Desposato. 2012. "The New Federalism of Mexico's Party System." Journal of Politics in Latin America 4(2): 3-38.

Carey, John M. 2007. “Competing Principals, Political Institutions, and Party Unity in Legislative Voting." American Journal of Political Science 51(1): 92-107.

Casar, Ma Amparo. 2002. "Executive-Legislative Relations: The Case of Mexico (1946-1997)." In Legislative Politics in Latin America, edited by Scott J. Morgenstern and Benito Nacif. Cambridge: Cambridge University Press, 114-145.

Ceron, Andrea. 2015. "Brave Rebels Stay Home: Assessing the Effect of Intra-Party Ideological Heterogeneity and Party Whip on Roll-Call Votes." Party Politics 21(2): 246-258.

Davidson, Roger H., Walter J. Oleszek, and Thomas Kephart. 1988. "One Bill, Many Committees: Multiple Referrals in the U. S. House of Representatives." Legislative Studies Quarterly 13(1): 3-28. 
Díaz Gómez, Everardo Rodrigo. 2005. “Desempeño legislativo y disciplina partidista en México: la Cámara de Diputados, 2000-2003." Confines 2(3): 45-64.

Diermeier, Daniel, and Timothy J. Feddersen. 1998. "Cohesion in Legislatures and the Vote of Confidence Procedure." American Political Science Review 92(3):611-622.

Edwards, George C. III. 1976. "Presidential Influence in the House: Presidential Prestige as a Source of Presidential Power." American Political Science Review 70(1): 101-113.

Garrido, Sebastián and Flavia Freidenberg. 2020. “El poder del voto. Cambio electoral y sistema de partidos a nivel federal en México 2018." Política y Gobierno 28(2): 1-22.

González Casanova, Pablo. 1982. El estado y los partidos políticos en México. Mexico City: Era.

González Tule, Luis Antonio. 2010. “Cohesión interna en el PRI frente a la ausencia de liderazgo unificador." Polis 6(1): 97-130.

Gronke, Paul, Jeffrey Koch, and J. Matthew Wilson. 2003. "Follow the Leader? Presidential Approval, Presidential Support, and Representatives' Electoral Fortunes." Journal of Politics 65(3): 785-808.

Gutiérrez, Silvia and Yazmín Cuevas. 2012. "Representaciones sociales de Enrique Peña Nieto, candidato a la presidencia de México 2012-2018, en la prensa escrita." Cultura y Representaciones Sociales 7(13): 63-95.

Hernández Rodríguez, Rogelio. 2009. “Una competencia sin reglas: La candidatura presidencial de Roberto Madrazo." Política y Gobierno 16(2): 15-49.

Hix, Simon. 2004. "Electoral Institutions and Legislative Behavior-Explaining Voting Defection in the European Parliament." World Politics 56(2):194-223.

Hix, Simon, Abdul Noury and Gérard Roland. 2005. "Power to the Parties: Cohesion and Competition in the European Parliament 1979-2001." British Journal of Political Science 35(2): 209-234.

Instituto Nacional de Estadística, Geografía e Informática (INEGI). 2020. "Indicador Trimestral de la Actividad Económica Estatal." Retrieved November 30, 2019 from https:// www.inegi.org.mx/temas/itaee/

Jones, Mark P., Sebastian Saiegh, Pablo T. Spiller and Mariano Tommasi. 2002. "Amateur Legislators-Professional Politicians: The Consequences of Party-Centered Electoral Rules in a Federal System." American Journal of Political Science 46(3): 356-369.

Kerevel, Yann P. 2015. "(Sub)National Principals, Legislative Agents: Patronage and Political Careers in Mexico." Comparative Political Studies 48(8): 1020-1050.

Klesner, Joseph L. 2005. "Electoral Competition and the New Party System in Mexico." Latin American Politics and Society 47(2): 103-142.

Langston, Joy. 2001. “Why Rules Matter: Changes in Candidate Selection in Mexico's PRI, 1988-2000." Journal of Latin American Studies 33(3): 485-511.

Langston, Joy. 2006. "The Changing Party of the Institutional Revolution: Electoral Competition and Decentralized Candidate Selection." Party Politics 12(3): 395-413.

Langston, Joy. 2008. "Legislative Recruitment in Mexico." In Pathways to Power: Political Recruitment and Candidate Selection in Latin America, edited by Peter Siavelis and Scott Morgenstern. University Park: The Pennsylvania State University Press, 143-163.

Langston, Joy. 2010. "Governors and 'Their' Deputies: New Legislative Principals in Mexico." Legislative Studies Quarterly 35(2): 235-258.

Langston, Joy. 2019. De la hegemonía a la ingnominia: El PRI de México. Mexico City: CIDE.

Lebo, Matthew J., and Andrew J. O'Geen. 2011. “The President's Role in the Partisan Congressional Arena." Journal of Politics 73(3): 718-734.

Light, Paul C. 1999. The President's Agenda: Domestic Policy Choice from Kennedy to Clinton. Baltimore: Johns Hopkins University Press.

Mainwaring, Scott. 1999. Rethinking Party Systems in the Third Wave of Democratization: The Case of Brazil. Stanford: Stanford University Press.

Márquez, Javier. 2019. "Poll of Polls." ORACULUS. Retrieved December 14, 2019 from https://oraculus.mx/aprobacion-presidencial/ 
Martínez Carmona, Carlos. 2017, 19 June. “A un año del fracaso de la iniciativa presidencial en favor del matrimonio gay." Movimientos e Instituciones. Retrieved October 20, 2019 from http:/ / movin.laoms.org/2017/06/19/fracaso-iniciativa-matrimonio-gay/

Mayhew, David. 1974. Congress: The Electoral Connection. New Haven: Yale University Press.

Meyer Cosío, Lorenzo. 1996. "La crisis del presidencialismo Mexicano. Recuperación espectacular y recaída estructural, 1982-1996." Foro Internacional 36(1-2): 11-30.

Miranda, Miguel Ángel Romero. 2018. "Notas acerca de la dramática derrota histórica del PRI." El Cotidiano 211: 67-85.

Mirón Lince, Rosa María. 2014. “El Partido Revolucionario Institucional: Recuperación electoral y recomposición organizativa en un escenario competitivo." El Cotidiano 187: 137-150.

Moe, Terry M., and William G. Howell. 1999. "The Presidential Power of Unilateral Action." Journal of Law, Economics, and Organization 15(1): 132-179.

Molinas, José, Aníbal Pérez-Liñán, and Sebastián Saiegh. 2004. "Political Institutions, Policymaking Processes, and Policy Outcomes in Paraguay, 1954-2003." Revista de Ciencia Política 24(2): 67-93.

Montiel Olea, José Luis and Carolin Pflueger. 2013. "A Robust Test for Weak Instruments." Journal of Business \& Economic Statistics 31(3): 358-369.

Nacif, Benito. 2002. "Understanding Party Discipline in the Mexican Chamber of Deputies: The Centralized Party Model." In Legislative Politics in Latin America, edited by Scott Morgenstern and Benito Nacif. Cambridge: Cambridge University Press, 254-284.

Navarrete Vela, Juan Pablo and Alberto Espejel Espinoza. 2018. “Composición de las dirigencias del Partido Acción Nacional, el Partido Revolucionario Institucional y el Partido de la Revolución Democrática después de la alternancia política (2002-2016)." Revista de El Colegio de San Luis 8(17): 163-236.

Neustadt, Richard E. 1960. Presidential Power. New York: Wiley

Olmeda, Juan C. 2009. “Federalismo revitalizado, pluralismo político y acción legislativa. Las relaciones entre los gobernadores Mexicanos y el Congreso de la Unión durante la última década." Revista Legislativa de Estudios Sociales y Opinión Pública 2(3): 103-132.

Persson, Torsten, and Guido Tabellini. 2003. The Economic Effects of Constitutions. Cambridge: MIT Press.

Pflueger, Carolin E. and Su Wang. 2015. "A Robust Test for Weak Instruments in Stata." The Stata Journal 15(1): 216-225.

Político. 2017, 15 June. "Reelección inicia en 2018, ¿Cómo funcionará?." Político MX. Retrieved September 29, 2019 from https:/ / politico.mx/central-electoral/elecciones-2018/ reelección-inicia-en-2018-cómo-funcionará/

Riker, William H. 1962. The Theory of Political Coalitions. New Haven: Yale University Press.

Rivers, Douglas, and Nancy L. Rose. 1985. "Passing the President's Program: Public Opinion and Presidential Influence in Congress." American Journal of Political Science 29(2): 183-196.

Rosas, Guillermo and Joy Langston. 2011. "Gubernatorial Effects on the Voting Behavior of National Legislators." The Journal of Politics 73(2): 477-493.

Samuels, David J. and Matthew S. Shugart. 2010. Presidents, Parties, and Prime Ministers: How the Separation of Powers Affects Party Organization and Behavior. Cambridge: Cambridge University Press.

Sistema de Información Legislativa (SIL). 2019. "Servicio de la gaceta parlamentaria." Cámara de Diputados del Congreso de la Unión. Retrieved October 8, 2019 from http:// gaceta.diputados.gob.mx/gp_inis.html

Sistema Nacional de Seguridad Pública (SNSP). 2019. "Datos abiertos de incidencia delictiva." Secretariado Ejecutivo del Sistema Nacional de Seguridad Pública. Retrieved from https://www.gob.mx/sesnsp/acciones-y-programas/datos-abiertos-de-incidencia-delictiva

Tamayo, Sergio. 2019. "La batalla por la ciudadanía. Narrativas de las concentraciones electorales en México 2018." Alteridades 29(57): 23-34. 
Valencia Escamilla, Laura. 2004. "La pluralidad política y su impacto en la disciplina parlamentaria." Sociológica 19(56): 13-53.

Volden, Craig, and Elizabeth Bergman. 2006. "How Strong Should Our Party Be? Party Member Preferences Over Party Cohesion." Legislative Studies Quarterly 31(1): 71-104.

Weldon, Jeffrey A. 2003. “El Congreso, las maquinarias políticas y el 'Maximato': las reformas antireleccionistas de 1933." In El Legislador a Examen: el Debate sobre la Reelección Legislativa en México, edited by Fernando F. Dworak. México, D.F.: Cámara de Diputados/ Fondo de Cultura Económica, 33-53.

Weldon, Jeffrey A. 2004a. "Changing Patterns of Executive-Legislative Relations in Mexico." In Dilemmas of Political Change in Mexico, edited by Kevin J. Middlebrook. London: Institute of Latin American Studies, 133-167.

Weldon, Jeffrey A. 2004b. "The Prohibition on Consecutive Reelection in the Mexican Congress." Election Law Journal 3(3): 574-579.

Wuhs, Steven. 2006. "Democratization and the Dynamics of Candidate Selection Rule Change in Mexico, 1991-2003." Mexican Studies/Estudios Mexicanos 22(1): 33-56.

Zepeda, Pedro J. 2017. "El pacto por México; un intento de gobierno de coalición." Research Paper no. 32. Mexico City: Mexican Senate.

Received: March 22, 2020

Accepted: March 29, 2021

Yen-Pin Su is Associate Professor in the Department of Political Science at National Chengchi University. He holds a Ph.D. in Political Science from the University of Pittsburgh. He specializes in comparative politics and political behavior, with a regional focus of Latin America. His research has been published in Comparative Politics, Party Politics, International Political Science Review, Latin American Politics and Society, and other outlets. Email: yenpinsu@nccu.edu.tw

Fabricio A. Fonseca is Assistant Professor in the Graduate Institute of Latin American Studies at Tamkang University. He holds a Ph.D. in Asia-Pacific Studies from National Chengchi University. His research interests include international relations, political economy, and comparative politics between East Asia and Latin America, particularly topics on Taiwan and Mexico. Email: faban. fonseca@gmail.com 
